\title{
Common Dermatologic Disorders in Down Syndrome: Systematic Review
}

Megan Lam ${ }^{1}$, BSc; Justin Di Lu ${ }^{1}$, MSc; Levi Elhadad ${ }^{2}$, BSc; Cathryn Sibbald ${ }^{3}$, BScPhm, MSc, MD; Raed Alhusayen ${ }^{4,5}$, MBBS, MSc

\footnotetext{
${ }^{1}$ Michael G. DeGroote School of Medicine, McMaster University, Hamilton, ON, Canada

${ }^{2}$ College of Biological Sciences, University of Guelph, Guelph, ON, Canada

${ }^{3}$ Section of Dermatology, Department of Paediatrics, SickKids Hospital, Toronto, ON, Canada

${ }^{4}$ Division of Dermatology, Department of Medicine, University of Toronto, Toronto, ON, Canada

${ }^{5}$ Division of Dermatology, Sunnybrook Health Sciences Centre, Toronto, ON, Canada
}

\author{
Corresponding Author: \\ Megan Lam, BSc \\ Michael G. DeGroote School of Medicine \\ McMaster University \\ 1280 Main St W \\ Hamilton, ON, L8S 4L8 \\ Canada \\ Phone: 16479188459 \\ Email: Megan.lam@medportal.ca
}

\begin{abstract}
Background: Down syndrome (DS) has been associated with cardiovascular, gastrointestinal, and immune-related abnormalities. Several dermatologic conditions, including hidradenitis suppurativa, have also been found to be associated with DS.

Objective: The objective of this study was to characterize the prevalence, presentation, and unique features of dermatologic disorders associated with DS.

Methods: Electronic searches of EMBASE (via Ovid), MEDLINE (via Ovid), and Web of Science databases were conducted on December 14, 2020. Observational studies including case reports of patients with DS presenting with concomitant primary dermatologic disorder were included.

Results: This systematic review captured 40 observational studies and 99 case reports, including 10 observational studies that examined the prevalence of common skin disorders in patients with DS. The most common dermatologic conditions reported includes atopic dermatitis ( 8 studies, $\mathrm{n}=180 ; 19.7 \%$ mean prevalence), hidradenitis suppurativa $(15, \mathrm{n}=478 ; 3.2 \%)$, ichthyosis $(4$, $\mathrm{n}=16 ; 4.7 \%)$, lichen nitidus $(6, \mathrm{n}=6 ; 1.1 \%)$, psoriasis $(21, \mathrm{n}=65 ; 4.8 \%)$, alopecia areata $(27, \mathrm{n}=253 ; 7.4 \%)$, vitiligo $(8, \mathrm{n}=40$; $4.4 \%)$, onychomycosis $(3, n=198 ; 24.7 \%)$, calcinosis cutis $(14, n=15)$, connective tissue nevi $(6, n=6)$, dermatofibroma $(3$, $n=3)$, melanoma $(3, n=3)$, syringomas $(14, n=182 ; 21.2 \%)$, and elastosis perforans serpiginosa $(19, n=24 ; 0.5 \%)$.

Conclusions: Our results indicate an increased prevalence of common cutaneous disorders in patients with DS, particularly infectious, inflammatory, autoimmune, and connective tissue conditions. Current guidelines for the screening, general management, and use of systemic immunomodulatory agents in this patient population are lacking. Patients with DS would benefit from screening for dermatologic disorders not otherwise regularly performed for earlier diagnosis and treatment.
\end{abstract}

Trial Registration: PROSPERO International Prospective Register of Systematic Reviews CRD42021226295; https://www.crd.york.ac.uk/PROSPERO/display_record.php?RecordID=226295

(JMIR Dermatol 2022;5(1):e33391) doi: $\underline{10.2196 / 33391}$

\section{KEYWORDS}

autoimmune; comorbidities; trisomy 21; inflammatory; Down syndrome; dermatology; hidradenitis suppurativa; systematic review 


\section{Introduction}

Down syndrome (DS) is one of the most common causes of intellectual disability in high-income countries and has been associated cardiovascular abnormalities, gastrointestinal defects, and immune-related disorders [1]. Dermatologic conditions are also found to be increased in patients with DS, including folliculitis, alopecia areata, and psoriasis [2,3]. A recent survey of 223 families with young adults with DS found that $56 \%$ suffered from a dermatological condition [4]. Identification and characterization of associated conditions, particularly those with unique clinical presentations in patients with DS, could help optimize early diagnosis and inform screening.

Thus, the aim of this systematic review was to summarize the prevalence of common dermatologic disorders in patients with DS and to characterize the presentation and unique features of dermatologic disorders when associated with DS.

\section{Methods}

\section{Overview}

This systematic review was conducted in accordance with PRISMA (Preferred Reporting Items for Systematic Reviews and Meta-Analyses) guidelines and was prospectively registered on PROSPERO (International Prospective Register of Systematic Reviews; CRD42021226295). The PRISMA guidelines are an evidence-based guide created to improve the reporting of systematic reviews and follow a 27-item standardized checklist addressing items to include introduction, methods, results, and discussion sections.

\section{Search Strategy and Inclusion Criteria}

We searched EMBASE (via Ovid), MEDLINE (via Ovid), and Web of Science electronic databases from their respective dates of conception to December 14, 2020, with no restrictions. Our search strategy comprised key terms for DS and skin conditions, including specific disorders such as atopic dermatitis, psoriasis, and vitiligo.

We included any observational studies including case reports of patients with DS presenting with concomitant dermatologic disorder including, but not limited to, atopic dermatitis, psoriasis, vitiligo, alopecia areata, acne vulgaris, onychomycosis, hidradenitis suppurativa, and seborrheic dermatitis. Abstracts and unpublished studies were excluded.

\section{Data Extraction and Synthesis}

We screened titles and abstracts (ML and JDL), followed by full texts (ML, LE, and JDL) independently and in duplicate. When necessary, discrepancies were resolved by consulting a senior author (CS and RA). The following data were extracted using a standardized form: study characteristics (author, year, study design, country, and participant source); population characteristics (number of participants, age, sex, race, comorbid conditions, and concurrent medications); disease factors (subtype, age of onset, affected areas, and severity); treatment factors (current treatment, duration, effectiveness, past treatments, and complications of treatment); follow-up interval; and prevalence or incidence statistics if reported.

The quality assessment of included observational studies was performed using the National Institutes of Health's National Heart Lung and Blood Institute quality assessment tools. The National Institutes of Health quality assessment tools have been used in the systematic evidence review of national updates to clinical guidelines and offer nonnumeric methods for critical appraisal of the internal validity of a study, with specific tools for individual types of study designs, including controlled intervention, cross-sectional, and case-control studies. Reviewers respond "yes," "no," or "cannot determine/not reported/not applicable" in response to each item in the tool, which includes sources of bias, confounding, study power, and strength of causality, to assess the risk of bias in the study and determine a rating of "good," "fair," or "poor" quality. Case reports were evaluated for methodological quality using an updated 8-item tool proposed by Murad et al [5]. We anticipated that much of the body of evidence from this systematic review would consist primarily of uncontrolled clinical observations, and this tool was selected as it provided a tailored approach to the assessment of evidence derived from case reports and case series, based on 4 domains (selection, ascertainment, causality, and reporting).

Qualitative syntheses for study characteristics, as well as key characteristic, outcomes, and treatment regimens, were summarized for each dermatologic condition. Where applicable, weighted means were calculated for observational studies reporting the prevalence of skin disorders in persons with DS.

\section{Results}

\section{Overview}

Ultimately, 40 observational studies and 99 case reports were included in this systematic review (Table 1 and Figure 1). 
Table 1. Summary of search results by dermatologic condition.

\begin{tabular}{|c|c|c|c|c|}
\hline \multirow[t]{2}{*}{ Dermatologic condition } & \multicolumn{3}{|c|}{ Number of studies } & \multirow{2}{*}{$\begin{array}{l}\text { Weighted mean preva- } \\
\text { lence, }{ }^{\text {a }} \%(\mathrm{n} / \mathrm{N})\end{array}$} \\
\hline & Case report, $\mathrm{n}$ & CS/Cohort, ${ }^{b} \mathrm{n}$ & Observational, n & \\
\hline \multicolumn{5}{|l|}{ Inflammatory skin conditions } \\
\hline Acne vulgaris & 0 & 0 & 7 & $14.7(149 / 1017)$ \\
\hline Atopic dermatitis & 2 & 0 & 6 & $19.7(178 / 903)$ \\
\hline Cheilitis & 0 & 0 & 6 & $8.4(68 / 805)$ \\
\hline Folliculitis & 1 & 0 & 7 & $21.2(213 / 1006)$ \\
\hline Hidradenitis suppurativa & 2 & 1 & 6 & $3.2(425 / 13266)$ \\
\hline Ichthyosis & 2 & 0 & 2 & $4.7(14 / 298)$ \\
\hline Keratosis pilaris & 0 & 0 & 9 & $8.6(97 / 1134)$ \\
\hline Lichen nitidus & 5 & 0 & 1 & $1.1\left(-^{\mathrm{c}}\right)$ \\
\hline Pityriasis rubra pilaris & 3 & 0 & 0 & - \\
\hline Psoriasis & 14 & 1 & 6 & $4.8(46 / 953)$ \\
\hline Seborrheic dermatitis & 0 & 0 & 8 & $18.5(212 / 1149)$ \\
\hline \multicolumn{5}{|l|}{ Autoimmune skin conditions } \\
\hline Alopecia areata & 11 & 5 & 11 & $7.4(190 / 2574)$ \\
\hline Vitiligo & 3 & 0 & 5 & $4.4(31 / 709)$ \\
\hline \multicolumn{5}{|l|}{ Infectious skin conditions } \\
\hline Leishmaniasis & 4 & 0 & 0 & - \\
\hline Onychomycosis & 0 & 2 & 3 & $24.7(188 / 761)$ \\
\hline Scabies & 7 & 0 & - & - \\
\hline Tinea capitis & 0 & 0 & 1 & $2.5(6 / 243)$ \\
\hline Tinea corporis & 0 & 0 & 2 & $2.0(9 / 446)$ \\
\hline Tinea cruris & 0 & 0 & 1 & $8.4(18 / 214)$ \\
\hline Tinea pedis & 0 & 0 & 4 & $30.9(190 / 615)$ \\
\hline \multicolumn{5}{|c|}{ Cutaneous birthmarks, tumors, and depositions } \\
\hline Café au lait macules & 0 & 0 & 5 & $3.8(24 / 633)$ \\
\hline Calcinosis cutis & 13 & 1 & 1 & $3.0(-)$ \\
\hline Connective tissue nevi & 6 & 0 & 0 & - \\
\hline Dermatofibroma & 3 & 0 & 0 & - \\
\hline Melanoma & 3 & 0 & 0 & - \\
\hline Syringoma & 8 & 0 & 6 & $21.2(174 / 821)$ \\
\hline \multicolumn{5}{|l|}{ Other skin conditions } \\
\hline Acanthosis nigricans & 0 & 0 & 3 & $30.7(67 / 218)$ \\
\hline Cutis marmorata & 0 & 0 & 3 & $8.4(28 / 335)$ \\
\hline EPS $^{\mathrm{d}}$ & 16 & 2 & 1 & $0.5(1 / 203)$ \\
\hline Other case reports ${ }^{\mathrm{e}}$ & 7 & - & - & - \\
\hline
\end{tabular}

${ }^{\mathrm{a}}$ Weighted mean prevalence of patients with dermatologic condition in a population with Down syndrome, calculated from values reported in observational studies.

${ }^{\mathrm{b}} \mathrm{CS} /$ Cohort: Case series or cohort studies with no prevalence value provided.

${ }^{\mathrm{c}}$ Not available.

${ }^{\mathrm{d}}$ EPS: elastosis perforans serpiginosa. 
${ }^{\mathrm{e}}$ Other case reports examined patients with actinomycetoma, cheilitis granulomatosa, epidermolysis bullosa, generalized perforating granuloma annulare, keratosis follicularis spinulosa decalvans, reactive perforating collagenosis, and familial urticaria pigmentosa.

Figure 1. Study selection methodology.

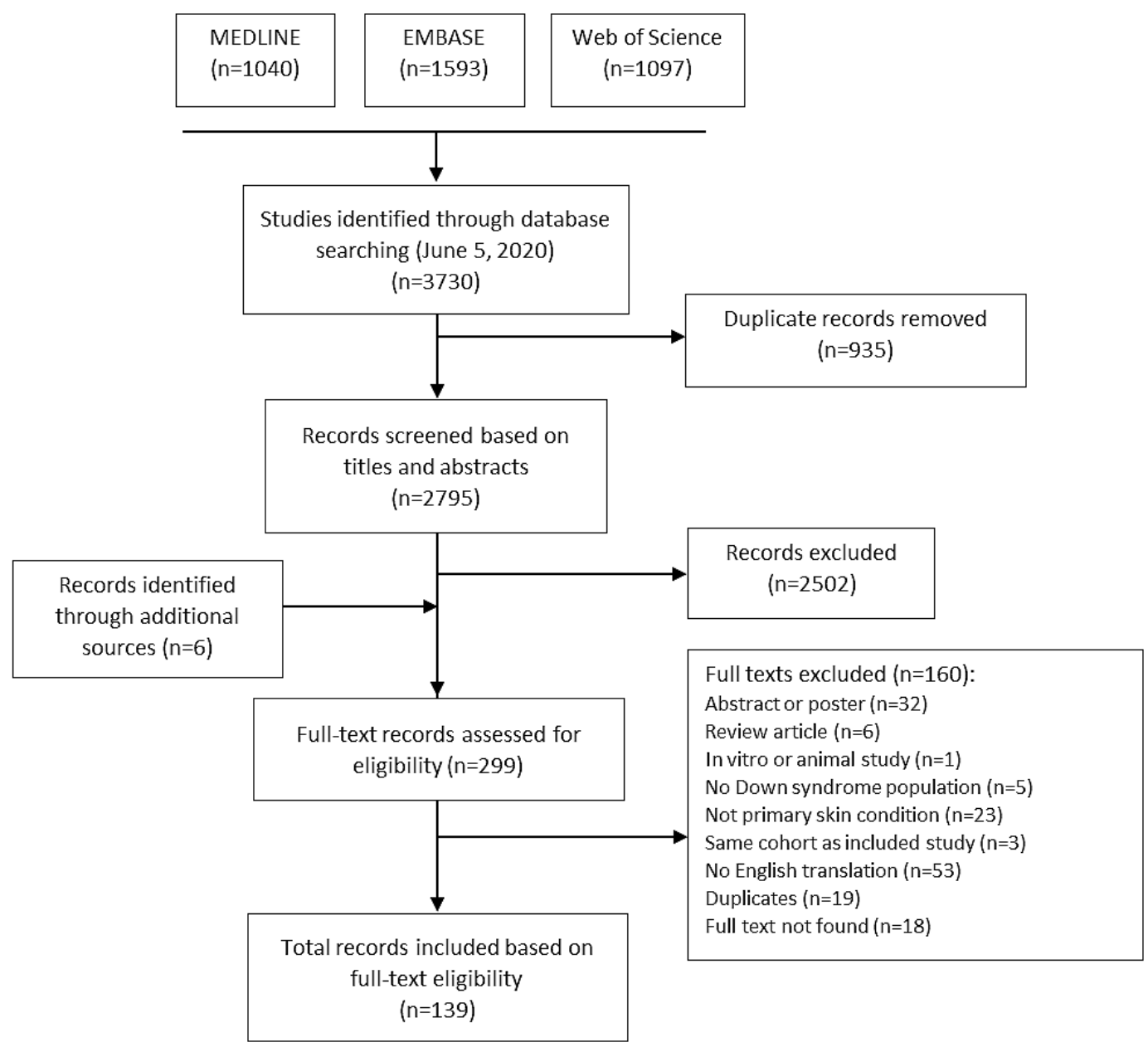

Ten of the observational studies reported the prevalence of cutaneous disorders in general in populations with DS (Table 2).
Case reports were primarily carried out in the United States $(n=28)$, Japan $(n=13)$, and Italy $(n=11)$. Quality assessment yielded the following ratings for case reports: good, $n=25$; fair, $\mathrm{n}=70$; and poor, $\mathrm{n}=5$. It also yielded the following ratings for observational studies: good, $n=25$; fair, $n=12$; and poor, $n=3$. 
Table 2. Observational studies examining prevalence of dermatologic conditions in patients with Down syndrome.

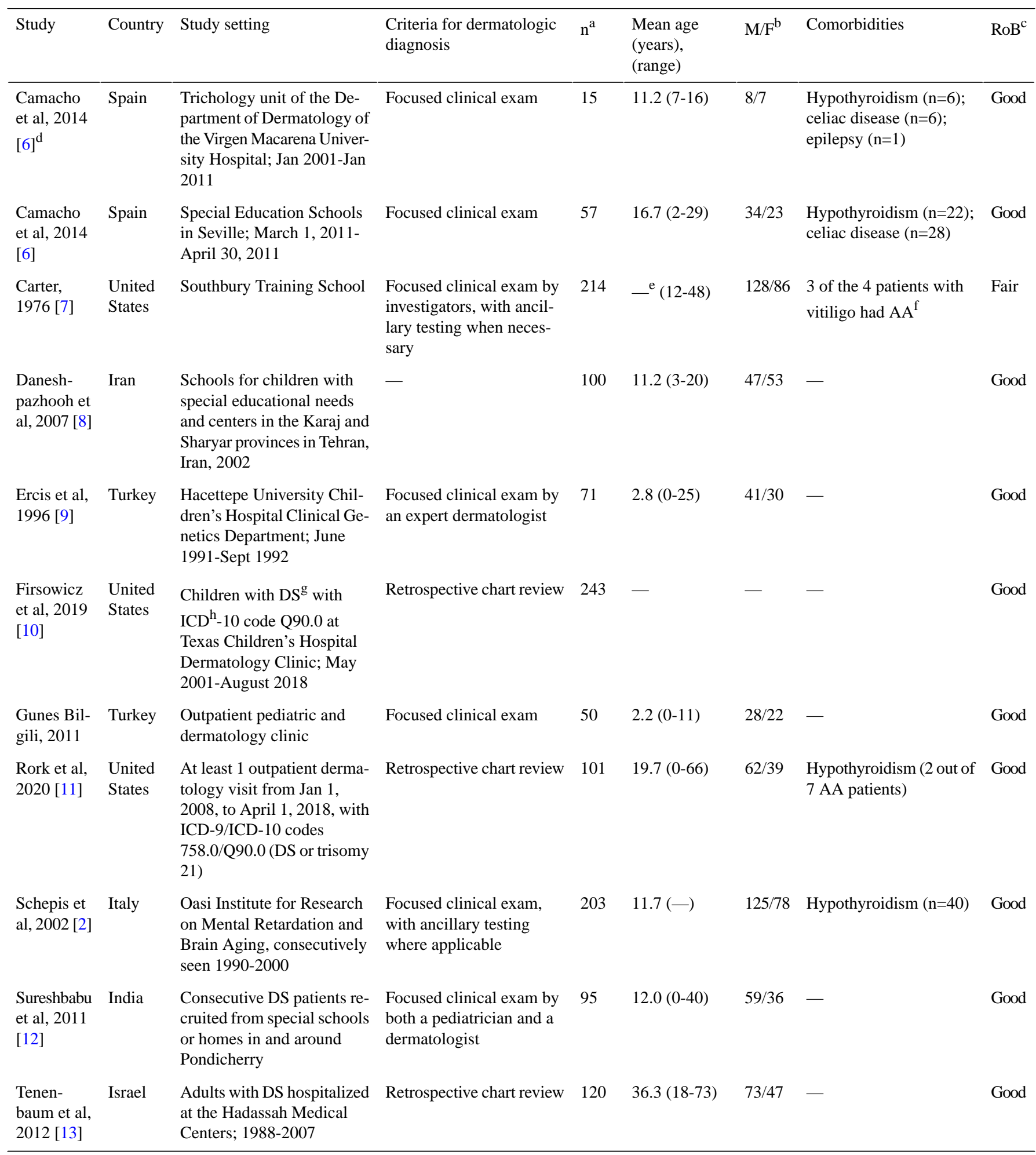

${ }^{\mathrm{a}}$ Total number of patients with Down syndrome.

${ }^{\mathrm{b}} \mathrm{M} / \mathrm{F}$ : male/female.

${ }^{\mathrm{c}} \mathrm{RoB}$ : risk of bias.

${ }^{\mathrm{d}}$ Camacho et al [6] had 2 separate cohorts of patents with Down syndrome.

e Not available.

${ }^{\mathrm{f}} \mathrm{AA}$ : alopecia areata.

gDS: Down syndrome.

${ }^{\mathrm{h}} \mathrm{ICD}$ : International Classification of Diseases and Related Health Problems. 


\section{Inflammatory Skin Conditions}

\section{Atopic Dermatitis}

Six observational studies reported the prevalence of atopic dermatitis (AD) in their cohorts with DS. The mean prevalence was $19.7 \%$ (178 patients with AD out of 903 total patients with DS) $[2,6,7,9,10,14]$. The study by Schepis et al [14] in 1997 was the only observational study to examine AD specifically and compared its prevalence in a group with DS to a control group. The DS and control groups were reported to have the same prevalence of $\mathrm{AD}(3.0 \%)$.

Two case reports of patients with DS having scabies were also reported to have a history of $\mathrm{AD}[15,16]$.

\section{Hidradenitis Suppurativa}

Six observational studies with a mean prevalence of $3.2 \%$ (425/13266) of hidradenitis suppurativa (HS) in patients with DS were included [6,10,11,17-19]. One study reported a significantly increased risk of HS in patients with DS compared with controls after adjusting for age, sex, race, and obesity (odds ratio 5.24, 95\% CI 4.62-5.94) [18]. Six other observational studies reported a weighted mean prevalence of $2.5 \%(40 / 1609)$ of DS among patients with HS [20-25]. The mean age of onset for HS in patients with DS in observational studies was 14.3 years.

There were also 2 case reports and 1 case series examining HS in patients with DS [26-28].

\section{Ichthyosis}

Two observational studies reported the prevalence of ichthyosis vulgaris in patients with DS, with a mean prevalence of $4.7 \%$ $(14 / 298)[2,12]$.

Two case reports included patients with features of ichthyosis vulgaris; both cases were reported to clinically resemble ichthyosis vulgaris and were supported by histologic findings but were missing features of early onset in life and positive family history $[29,30]$.

\section{Lichen Nitidus}

One observational study reported a prevalence of $1.1 \%(1 / 95)$ of lichen nitidus (LN) in patients with DS [12].

Five case reports of LN were reported (Multimedia Appendix 1) [31-35]. One other case report in French (not included in this systematic review) presented a patient with DS having LN with associated megacolon [36].

\section{Pityriasis Rubra Pilaris}

Three case reports of pityriasis rubra pilaris (PRP) were found (Multimedia Appendix 2) on 2 female patients with circumscribed juvenile PRP (type IV) [37,38] and 1 male patient with classic juvenile PRP (type III) [39]. Accordingly, 2 patients were treated with oral etretinate with long-term control of symptoms [38,39], while 1 patient was treated effectively with topical $0.1 \%$ trans retinoic acid [37].

\section{Psoriasis}

Six observational studies reported the prevalence of psoriasis in a population with DS, with a weighted mean prevalence of
$4.8 \%(46 / 953) \quad[2,6,7,10,11,13]$. One observational study reported $2(0.4 \%)$ patients with DS in a cohort of 419 children with psoriasis [40].

Moreover, there were 14 case reports and 1 case series with 17 patients in total, where $3(17.6 \%)$ of the patients had psoriatic arthritis (Multimedia Appendix 3) [29,41-54]. Six studies reported failed or ineffective systemic treatment with immunosuppressants $[41,45,46,51,52]$, including the study by Adamcyzk et al [41], who reported discontinuing cyclosporin A treatment due to elevated liver enzymes, and Alcaide et al [42], who reported contraindications for cyclosporin and methotrexate due to renal and liver problems, respectively. Of the 8 patients treated successfully with systemic immunosuppressive treatments, 5 patients were treated with biologics (etanercept [41,42], ustekinumab [52], infliximab [51], adalimumab [46]), and 3 with conventional systemic medications including cyclosporin [47], azathioprine [45], and oral or intramuscular hydrocortisone [53].

\section{Autoimmune Skin Conditions}

\section{Alopecia Areata}

Eleven observational studies examined the prevalence of alopecia areata (AA) in populations with DS, with a weighted mean prevalence of $7.4 \%$ (190 patients with AA, out of 2574 patients with DS), and a range of 1.4\%-21.0\% [2,6-12,55-57]. One observational study reported $5(1.3 \%)$ patients with DS in a cohort of 392 patients with AA [58].

Three observational studies examined only patients with both AA and DS, with a total of 44 patients and a weighted mean age of onset of 7.0 years (Multimedia Appendix 4) [59-61]. Lima Estafan et al [59] also reported a mean duration of 2.7 years and recurrence in $27.7 \%$ of patients. The study found no concomitant vitiligo or autoimmune disease, as well as no first-degree relatives with AA [59]. By contrast, Ramot et al [60] reported that $8(57 \%)$ of patients had a 1 st or 2 nd degree relative with AA. Ramot et al [60] and Schepis et al [61] reported $6(42.9 \%)$ and $4(33.3 \%)$ with thyroid abnormalities, and $1(7.1 \%)$ and $4(33.3 \%)$ with celiac disease.

In addition, 11 case reports and 2 case series presented 14 patients with AA and DS, with a mean age of onset of 7.0 (SD 4.5) (Multimedia Appendix 5) [26,49,54,62-71]. Three studies presented patients with normal hair growth in areas of comorbid inflammatory skin disease (HS [26] and psoriasis [49,54]), also known as the Renbok phenomenon. Moreover, 5 patients had concomitant hypothyroidism [26,49,67,69,71], with 1 patient demonstrating complete resolution of hair regrowth 12 months after starting thyroxine treatment [69].

\section{Vitiligo}

Five observational studies with a weighted mean prevalence of $4.4 \%(31 / 709)$ of vitiligo in patients with DS were included $[6-8,10,12]$. Two observational studies reported a mean prevalence of $0.6 \%(6 / 1030)$ of DS in a cohort of patients with vitiligo [72,73].

Three case reports on patients with DS having vitiligo were included, associated with LN (aged 4 years, female) [31], leishmaniasis (aged 35 years, male) [74], and PRP (aged 30 
years, female) [37]. One patient also had hypothyroidism and type II diabetes mellitus [74].

\section{Infectious Skin Conditions}

\section{Fungal Infections}

Three observational studies examining the prevalence of onychomycosis among patients with DS had a weighted mean prevalence of $24.7 \%$ (188/761) [2,7,10,11]. Two other observational studies examining the prevalence of DS in patients with onychomycosis had a mean prevalence of $30.3 \%(10 / 33)$ [75,76]. One other cohort study examining only patients with DS having onychomycosis treated with terbinafine reported that all 32 patients had negative cultures after 24 weeks of treatment [77].

Additionally, 4 observational studies reported a mean weighted prevalence of 30.9\% (190/615) of tinea pedis; 2 studies reported a weighted mean prevalence of $2.0 \%$ (9/446) of tinea corporis; 1 study reported a prevalence of $8.4 \%(18 / 214)$ of tinea cruris; and 1 study reported a prevalence of $2.5 \%(6 / 243)$ of tinea capitis.

Goulen et al [78] reported the successful treatment of a 5-year-old female patient with a Trichophyton rubrum-infected toenail, with 12 months of griseofulvin, followed by 6 months of daily terbinafine.

\section{Other Infections}

There was 1 observational study of a scabies outbreak among persons with mental disability, which reported an index case of a 16-year-old patient with DS [79]. There were also 7 case reports of scabies (Multimedia Appendix 6) [15,16,80-84], where 4 of the cases reported an initial misdiagnosis of scabies, and the patients were instead treated ineffectively for presumed onychomycosis, psoriasis, eczema, tinea corporis, and psoriasiform dermatitis [16,80-82,84]. There were also 4 case reports of leishmaniasis (Multimedia Appendix 7) [74,85-87] and 1 case report of actinomycetoma [88].

\section{Cutaneous Birthmarks, Tumors, and Depositions \\ Calcinosis Cutis}

Thirteen case reports and 1 case series reported 15 patients with calcinosis cutis, where 12 were diagnosed with milia-like calcinosis cutis [89-100], 1 with dystrophic calcinosis cutis [101], and 1 unspecified case (Multimedia Appendix 8) [102]. There were no reports of abnormal laboratory values, including serum calcium, phosphate, and parathyroid hormone levels. Six studies reported concomitant presentation of syringomas, with 5 cases of palpebral syringomas [90,94,96,100,102], and 3 studies that reported perilesional syringomas [90,97,102].

\section{Connective Tissue Nevi}

Six case reports presenting patients with DS having collagenomas or connective tissue nevi were included, with a mean age of 22.8 (SD 14.9) years [30,95,103-106]. No history of trauma was reported.

\section{Dermatofibroma}

Three cases of multiple dermatofibromas were included (Multimedia Appendix 9) [107-109], commonly defined as the development of 5 to 8 lesions within 4 months. The number of lesions at the time of report ranged from 6 to approximately 30 . None had evidence of immunosuppression, although 1 patient presented with mild lymphopenia [109], and another with a history of acute megakaryoblastic leukemia [107].

One other case report in Spanish (not included in this systematic review) presented 3 patients with DS having multiple dermatofibromas, where 1 patient was immunosuppressed receiving methotrexate [110].

\section{Melanoma}

Three patients with cutaneous melanomas were reported (Multimedia Appendix 10) [111-113]. Jafarian et al [111] reported an 11-year-old patient with a stage IIA melanoma of the leg. Satge et al [112] reported a 19-year-old female patient with superficial spreading melanoma (Clark level II) in the lumber region. Lastly, Nakano et al [113] reported a 39-year-old patient with an acral lentiginous melanoma (Clark level V) of the right foot with central ulcer. No evidence of metastasis was found in any of the patients at the time of presentation, and all were treated with surgical excision.

\section{Syringomas}

Six observational studies examined the prevalence of syringomas in patients with DS, with a weighted mean prevalence of $21.2 \%$ (174/821) (Multimedia Appendix 11) [2,6-8,114,115]. Two of these observational studies only investigated for syringomas, published in 1964 and 1991 [114,115]. Feingold et al [115] also included an age-matched control group, which had a prevalence of $2.0 \%$ of syringomas, and reported that cases of syringomas in patients with DS did not present concurrent hypothyroidism or congenital heart disease.

Eight case reports included patients with DS having syringomas [90,94,96,100,102,104,116,117]. Five reported periorbital or palpebral syringomas $[90,96,100,102,117]$. One report described a case of eruptive syringomas over the trunk over the course of 1 month [116].

\section{Other Skin Conditions}

\section{Elastosis Perforans Serpiginosa}

One observational study reported a prevalence of elastosis perforans serpiginosa (EPS) in 203 patients with DS of $0.5 \%$ [2].

Moreover, 16 case reports and 2 case series examined 23 patients with EPS, with a mean age of 22.1 (SD 9.2) years (Multimedia Appendix 12) [83,118-134]. Three studies reported spontaneous resolution of lesions, ranging from 6 months to 3 years $[129,133,134]$. Topical steroids were reported to be ineffective in 7 cases $[83,118,122,123,132,133]$.

\section{Other Case Reports}

Other case reports involving primary skin conditions in patients with DS include anetoderma secondary to folliculitis [135], cheilitis granulomatosa [136], epidermolysis bullosa [137], generalized perforating granuloma annulare [138], keratosis follicularis spinulosa decalvans [139], reactive perforating collagenosis [140], and familial urticaria pigmentosa [141]. 


\section{Discussion}

\section{Principal Findings}

This systematic review captured 40 observational studies and 99 case reports, including 10 observational studies that examined the prevalence of common skin disorders in general in patients with DS. Our results indicate a potential association between DS and common cutaneous disorders including alopecia areata, acne vulgaris, hidradenitis suppurativa, and seborrheic dermatitis, although the scope of evidence in the literature is quite limited. Less common skin disorders including calcinosis cutis, eruptive syringomas, and multiple dermatofibromas were frequently described in case reports of patients with DS. Connective tissue conditions were also observed frequently in patients with DS including EPS, collagenomas, and reactive perforating collagenosis. Some cases of EPS also had high incidence of joint hyperextensibility and premature skin aging $[120,126]$, suggesting a presence of connective tissue dysplasia.

Autoimmune conditions including psoriasis and AA have been linked to immune dysregulation in patients with DS [26,50]. Increased activity of CD4 T-lymphocytes and their proinflammatory cytokines (IFN- $\gamma$ [interferon gamma] and TNF- $\alpha$ [tumor necrosis factor alpha]) are also involved in psoriasis pathogenesis [46]. Patients with DS may also therefore be more prone to severe cases of infestation and bacterial proliferation in the skin $[10,86]$. The cases of scabies reported in this review were extensive, tended to be generalized to the whole body, and were often clinically misdiagnosed and treated ineffectively, for instance as $\mathrm{AD}$ or psoriasis, before the diagnosis of scabies was made. The most recent guidelines set by the American Academy of Pediatrics for the management of children with DS do not provide any skin care recommendations for patients with DS [142]. Given the prevalence of skin disorders as outlined in this review, patients with DS would benefit from screening of dermatologic disorders that are not otherwise regularly performed for earlier diagnosis and treatment. However, patients with DS may experience difficulties accessing adequate services for the screening and treatment of cutaneous disease, for instance, given cognitive disabilities, social barriers, and potentially impairing comorbid physical and mental health conditions. Potential difficulties adhering to screening and treatment regimens, as well as preventative measures such as sun protection, may also pose challenges to interventions.

With the exception of 1 case [82], none of the patients were medically immunosuppressed. Nevertheless, most reports of scabies included in this review had superimposed bacterial infections and received antibiotic treatment. Similarly, with infectious and inflammatory conditions in and around the pilosebaceous unit including acne vulgaris, folliculitis, and HS, immunodeficiency predisposes patients to these conditions. An association with HS and DS has been previously outlined in a recent meta-analysis by Lam et al [143], which not only demonstrated a significant association, but also a younger age of onset for patients with DS for HS.

Standardized guidelines for systemic immunomodulatory agents in this patient population are lacking, and reports of systemic immunosuppressants in the treatment of cutaneous disorders in patients with DS are limited. The theoretical increased risk of infection and other complications, possibly due to concerns of low compliance or other comorbidities including congenital heart, haemato-oncological and endocrinological disorders, as well as immunological alterations lead to prescriber hesitation when considering biologics in severe cases refractory to other treatments [52]. Several patients described in this review presented cases where treatment with immunomodulatory agents were discontinued due to adverse effects or contraindicated due to preexisting conditions; however, considerations in the safety of these systemic agents in patients with DS remain unclear $[52,144]$.

\section{Limitations}

Our study had several limitations. First, our calculated prevalence of skin conditions may have overestimated real prevalence, as studies that either did not assess for or found no cases were not included in weighted mean calculations. Our conclusions based on prevalence are also limited by insufficient studies with age-matched controls to provide comparison of prevalence in a matched population. Selection bias for patients included in case reports and case series limits interpretation. Additionally, patients with DS may be more likely to interact with health care providers given their increased risk of comorbidities and medical complications, which may result in an increase in diagnoses of cutaneous disease, among other diseases. Lastly, 53 studies were not included due to language restrictions.

\section{Conclusions}

This review highlights the need for additional data on the true prevalence and onset of dermatologic conditions in persons with DS. Particularly for conditions including psoriasis and HS, early diagnosis and treatment as well as appropriate screening will be important. Patients with DS may also be at an increased risk of cutaneous infections, and possible misdiagnoses could lead to increased severity at presentation. For patients with DS who may have difficulty communicating their symptoms, screening for and recognizing the associated skin disorders in this population should be incorporated as a necessary part of care.

\section{Conflicts of Interest}

RA is a member of the Editorial Board of JMIR Dermatology.

\section{Multimedia Appendix 1}

Summary of case reports of Down syndrome patients with lichen nitidus. [DOCX File, 14 KB-Multimedia Appendix 1] 


\section{Multimedia Appendix 2}

Summary of case reports of Down syndrome patients with pityriasis rubra pilaris.

[DOCX File, 14 KB-Multimedia Appendix 2]

\section{Multimedia Appendix 3}

Summary of case reports of Down syndrome patients with psoriasis.

[DOCX File, 17 KB-Multimedia Appendix 3]

\section{Multimedia Appendix 4}

Observational studies examining only patients with both Down syndrome and alopecia areata.

[DOCX File, 14 KB-Multimedia Appendix 4]

\section{Multimedia Appendix 5}

Summary of case reports of Down syndrome patients with alopecia areata.

[DOCX File, 16 KB-Multimedia Appendix 5]

\section{Multimedia Appendix 6}

Summary of case reports of Down syndrome patients with scabies infestation.

[DOCX File, 15 KB-Multimedia Appendix 6]

\section{Multimedia Appendix 7}

Summary of case reports of Down syndrome patients with leishmaniasis infestation.

[DOCX File, $14 \mathrm{~KB}-$ Multimedia Appendix 7]

\section{Multimedia Appendix 8}

Summary of case reports of Down syndrome patients with calcinosis cutis.

[DOCX File, 15 KB-Multimedia Appendix 8]

\section{Multimedia Appendix 9}

Summary of case reports of Down syndrome patients with dermatofibromas.

[DOCX File, $14 \mathrm{~KB}$-Multimedia Appendix 9]

\section{Multimedia Appendix 10}

Summary of cases of Down syndrome patients with confirmed melanoma.

[DOCX File, 15 KB-Multimedia Appendix 10]

\section{Multimedia Appendix 11}

Summary of case reports of Down syndrome patients with syringoma(s).

[DOCX File, 14 KB-Multimedia Appendix 11]

\section{Multimedia Appendix 12}

Summary of case reports of Down syndrome patients with elastosis perforans serpiginosa.

[DOCX File, 17 KB-Multimedia Appendix 12]

\section{References}

1. Asim A, Kumar A, Muthuswamy S, Jain S, Agarwal S. "Down syndrome: an insight of the disease". J Biomed Sci 2015 Jun 11;22(1):41-49 [FREE Full text] [doi: 10.1186/s12929-015-0138-y] [Medline: 26062604]

2. Schepis C, Barone C, Siragusa M, Pettinato R, Romano C. An updated survey on skin conditions in Down syndrome. Dermatology 2002 Oct 21;205(3):234-238. [doi: 10.1159/000065859] [Medline: 12399669]

3. Yahav D, Franceschini E, Koppel F, Turjeman A, Babich T, Bitterman R, Bacteremia Duration Study Group. Seven Versus 14 Days of Antibiotic Therapy for Uncomplicated Gram-negative Bacteremia: A Noninferiority Randomized Controlled Trial. Clin Infect Dis 2019 Sep 13;69(7):1091-1098. [doi: 10.1093/cid/ciy1054] [Medline: 30535100] 
4. Pikora TJ, Bourke J, Bathgate K, Foley K, Lennox N, Leonard H. Health conditions and their impact among adolescents and young adults with Down syndrome. PLoS One 2014 May 12;9(5):e96868 [FREE Full text] [doi: 10.1371/journal.pone.0096868] [Medline: 24818963]

5. Murad MH, Sultan S, Haffar S, Bazerbachi F. Methodological quality and synthesis of case series and case reports. BMJ Evid Based Med 2018 Apr 02;23(2):60-63 [FREE Full text] [doi: 10.1136/bmjebm-2017-110853] [Medline: 29420178]

6. Camacho FM, Mazuecos J, Ferrándiz L, Cantalejo C, Cabello Á. Phenotypical and dermatological findings of down syndrome in Southern Spain. European Journal of Pediatric Dermatology 2014;24(1):7-12 [FREE Full text]

7. Carter D. Alopecia Areata and Down Syndrome. Arch Dermatol 1976 Oct 01;112(10):1397-1399. [doi: 10.1001/archderm.1976.01630340015003]

8. Daneshpazhooh M, Nazemi TM, Bigdeloo L, Yoosefi M. Mucocutaneous findings in 100 children with Down syndrome. Pediatr Dermatol 2007 May;24(3):317-320. [doi: 10.1111/j.1525-1470.2007.00412.x] [Medline: $\underline{17542890]}$

9. Ercis M, Balci S, Atakan N. Dermatological manifestations of 71 Down syndrome children admitted to a clinical genetics unit. Clin Genet 1996 Nov;50(5):317-320. [doi: 10.1111/j.1399-0004.1996.tb02381.x] [Medline: 9007317]

10. Firsowicz M, Boyd M, Jacks SK. Follicular occlusion disorders in Down syndrome patients. Pediatr Dermatol 2020 Jan 18;37(1):219-221. [doi: 10.1111/pde.14012] [Medline: $\underline{31626333]}$

11. Rork JF, McCormack L, Lal K, Wiss K, Belazarian L. Dermatologic conditions in Down syndrome: A single-center retrospective chart review. Pediatr Dermatol 2020 Sep 10;37(5):811-816. [doi: 10.1111/pde.14214] [Medline: $\underline{32519435]}$

12. Sureshbabu R, Kumari R, Ranugha S, Sathyamoorthy R, Udayashankar C, Oudeacoumar P. Phenotypic and dermatological manifestations in Down Syndrome. Dermatology Online Journal 2011;17(2):3. [doi: 10.5070/D38jx5f2v2]

13. Tenenbaum A, Chavkin M, Wexler ID, Korem M, Merrick J. Morbidity and hospitalizations of adults with Down syndrome. Res Dev Disabil 2012 Mar;33(2):435-441. [doi: 10.1016/j.ridd.2011.09.026] [Medline: 22137940]

14. Schepis C, Barone C, Siragusa M, Romano C. Prevalence of atopic dermatitis in patients with Down syndrome: A clinical survey. Journal of the American Academy of Dermatology 1997 Jun;36(6):1019-1021. [doi: 10.1016/s0190-9622(97)80294-0]

15. Lee K, Heresi G, Al Hammoud R. Norwegian Scabies in a Patient with Down Syndrome. J Pediatr 2019 Jun;209:253-253.e1. [doi: 10.1016/j.jpeds.2019.01.057] [Medline: 30853199]

16. Nagsuk P, Moore R, Lopez L. A case report of crusted scabies in an adult patient with down syndrome. Dermatology Online Journal 2015;21(8):13. [doi: 10.5070/D3218028438]

17. Sechi A, Guglielmo A, Patrizi A, Savoia F, Cocchi G, Leuzzi M, et al. Disseminate Recurrent Folliculitis and Hidradenitis Suppurativa Are Associated Conditions: Results From a Retrospective Study of 131 Patients With Down Syndrome and a Cohort of 12,351 Pediatric Controls. Dermatol Pract Concept 2019 Jul 31;9(3):187-194. [doi: 10.5826/dpc.0903a03]

18. Garg A, Strunk A, Midura M, Papagermanos V, Pomerantz H. Prevalence of hidradenitis suppurativa among patients with Down syndrome: a population-based cross-sectional analysis. Br J Dermatol 2018 Mar 17;178(3):697-703. [doi:

10.1111/bjd.15770] [Medline: 28662304]

19. Poizeau F, Sbidian E, Mircher C, Rebillat A, Chosidow O, Wolkenstein P, et al. Prevalence and Description of Hidradenitis Suppurativa in Down Syndrome: A Cross-sectional Study of 783 Subjects. Acta Derm Venereol 2019 Mar 01;99(3):351-352 [FREE Full text] [doi: 10.2340/00015555-3095] [Medline: $\underline{\text { 30460373] }}$

20. Denny G, Anadkat MJ. Hidradenitis suppurativa (HS) and Down syndrome (DS): Increased prevalence and a younger age of hidradenitis symptom onset. J Am Acad Dermatol 2016 Sep;75(3):632-634. [doi: 10.1016/j.jaad.2016.04.045] [Medline: 27543219]

21. Giovanardi G, Chiricozzi A, Bianchi L, De Simone C, Dini V, Franceschini C, et al. Hidradenitis Suppurativa Associated with Down Syndrome Is Characterized by Early Age at Diagnosis. Dermatology 2018 Apr 24;234(1-2):66-70. [doi: 10.1159/000487799] [Medline: 29689550]

22. Mebazâa A, Ben Hadid R, Rouhou RC, Trojjet S, Euch DE, Mokni M, et al. Hidradenitis suppurativa: a debilitating disease with male predominance in Tunisia. Acta dermatovenerologica Alpina, Panonica, et Adriatica 2009 Dec;18(4):165-172. [doi: $10.5580 / 276 \mathrm{~d}]$

23. Tiri H, Jokelainen J, Timonen M, Tasanen K, Huilaja L. Somatic and psychiatric comorbidities of hidradenitis suppurativa in children and adolescents. J Am Acad Dermatol 2018 Sep;79(3):514-519. [doi: 10.1016/j.jaad.2018.02.067] [Medline: 29518461]

24. Yüksel M, Basım P. Demographic and Clinical Features of Hidradenitis Suppurativa in Turkey. J Cutan Med Surg 2020 Nov 07;24(1):55-59. [doi: 10.1177/1203475419887732] [Medline: $\underline{31698918]}$

25. Veraldi S, Guanziroli E, Benzecry V, Nazzaro G. Hidradenitis suppurativa in patients with Down syndrome. J Eur Acad Dermatol Venereol 2019 Oct 19;33 Suppl 6:34-35. [doi: 10.1111/jdv.15822] [Medline: 31535757]

26. Molinelli E, Sapigni C, D'agostino G, Brisigotti V, Campanati A, Offidani A. Renbök phenomenon in a Down syndrome patient with hidradenitis suppurativa and alopecia areata. Eur J Dermatol 2020 Aug 01;30(4):435-436. [doi: 10.1684/ejd.2020.3805] [Medline: 32969807]

27. Sehgal VN, Sehgal N, Sehgal R. Hidradenitis Suppurativa and Concomitant Down Syndrome: Literature Review of Other Associated Mucocutaneous Manifestations in Adults. Skinmed 2017;15(4):253-258. [Medline: 28859733]

28. Hamadah I, Haider M, Chisti M, Binamer Y. Hidradenitis Suppurativa in Down Syndrome: A Case Series. Pediatr Dermatol 2017 Jul 21;34(4):461-464. [doi: 10.1111/pde.13188] [Medline: 28636122] 
29. Nomura K. Ichthyosis and psoriasis in a patient with Down syndrome. J Dermatol 1999 Aug 09;26(8):538-540. [doi: 10.1111/j.1346-8138.1999.tb02043.x] [Medline: 10487012]

30. Kopec AV, Levine N. Generalized connective tissue nevi and ichthyosis in Down's syndrome. Arch Dermatol 1979 May;115(5):623-624. [Medline: 156007]

31. Agarwal S, Guglani V, Kumar B. Down's syndrome with lichen nitidus and segmental vitiligo. Indian J Dermatol Venereol Leprol 2009;75(6):627-629. [doi: 10.4103/0378-6323.57738] [Medline: 19915257]

32. Botelho LFF, Magalhães JPJD, Ogawa MM, Enokihara MMSS, Cestari SDCP. Generalized Lichen nitidus associated with Down's syndrome: case report. An Bras Dermatol 2012 Jun;87(3):466-468. [doi: 10.1590/s0365-05962012000300018] [Medline: 22714765]

33. Guliani A, Kumar S, Saikia UN, Vinay K. Generalized lichen nitidus: A rare cutaneous manifestation of down's syndrome. SKINmed 2019;17(2):141-142. [doi: 10.1046/j.1365-2230.2002.00971.x]

34. Henry M, Metry D. Generalized lichen nitidus, with perioral and perinasal accentuation, in association with Down syndrome. Pediatr Dermatol 2009;26(1):109-111. [doi: 10.1111/j.1525-1470.2008.00841.x] [Medline: 19250429]

35. Laxmisha C, Thappa D. Generalized lichen nitidus with Down syndrome. J Eur Acad Dermatol Venereol 2006 Oct;20(9):1156-1157. [doi: 10.1111/j.1468-3083.2006.01656.x] [Medline: 16987290]

36. Patrizi A, Di Lernia V, Pauluzzi P. [Generalized lichen niditus, trisomy 21 and congenital megacolon]. Ann Dermatol Venereol 1991;118(10):725. [Medline: 1838236]

37. Hazini AR, Rongioletti F, Rebora A. Pityriasis rubra pilaris and vitiligo in Down's syndrome. Clin Exp Dermatol 1988 Sep;13(5):334-335. [doi: 10.1111/j.1365-2230.1988.tb00716.x] [Medline: 2978467]

38. Holden C, Curley R. Down's syndrome and pityriasis rubra pilaris. Clin Exp Dermatol 1989 Jul;14(4):332. [doi: 10.1111/j.1365-2230.1989.tb01999.x] [Medline: 2531644]

39. Terasaki K, Kanekura T, Saruwatari H, Kanzaki T. Classical juvenile pityriasis rubra pilaris in a patient with Down syndrome. Clin Exp Dermatol 2004 Jan;29(1):49-51. [doi: 10.1111/j.1365-2230.2004.01449.x] [Medline: 14723722]

40. Kumar B, Jain R, Sandhu K, Kaur I, Handa S. Epidemiology of childhood psoriasis: a study of 419 patients from northern India. Int J Dermatol 2004 Sep;43(9):654-658. [doi: 10.1111/j.1365-4632.2004.02182.x] [Medline: 15357744]

41. Adamczyk M, Michalska-Jakubus M, Krasowska D. A 12-year-old Girl with Severe Plaque Psoriasis and Down Syndrome Treated Successfully with Etanercept. Acta Dermatovenerol Croat 2017 Jul;25(2):155-158. [Medline: 28871932]

42. Alcaide A, Barrera M, Habicheyn S, López N, Mendiola M, Herrera E. Safety of etanercept therapy in a patient with psoriasis, Down's syndrome and concomitant hepatitis C virus infection. J Eur Acad Dermatol Venereol 2008 Dec;22(12):1514-1516. [doi: 10.1111/j.1468-3083.2008.02693.x] [Medline: 18355196]

43. Fargnoli MC, Peris K, Frascione P, Barbati R, Anemona L, Uccini S, et al. Psoriasis, Kaposi's sarcoma and Hodgkin's disease in a patient with Down's syndrome. Dermatology 2004 Aug 19;209(2):158-159. [doi: 10.1159/000079604] [Medline: 15316174]

44. Hedayati B, Carley SK, Kraus CN, Smith J. Arcuate pink plaques in a female with Down syndrome. Int J Dermatol 2020 Apr 19;59(4):e127-e128. [doi: 10.1111/ijd.14687] [Medline: 31630390]

45. Jorgensen C, Bologna C, Sany J. Vasculitis and psoriatic arthritis associated with Down's syndrome. Clin Exp Rheumatol 1995;13(6):749-751. [Medline: 8835250$]$

46. Marmon S, Souza AD, Strober BE. Psoriasis and Down syndrome: A report of three cases and a potential pathophysiologic link. Dermatology Online Journal 2012;18(6):13. [doi: 10.5070/D305m5f4]

47. Morita A, Kawakami Y, Kaji T, Hirai Y, Miyake T, Takahashi M, et al. Pediatric-onset annular pustular psoriasis in a patient with Down syndrome. J Dermatol 2019 Oct 03;46(10):e367-e368. [doi: 10.1111/1346-8138.14896] [Medline: 31050001]

48. Rotchford JP. Extreme hyperkeratotic psoriasis in a mongoloid. A case report. Arch Dermatol 1961 Jun 01;83(6):973-976. [doi: 10.1001/archderm.1961.01580120085021] [Medline: 13743796]

49. Schepis C, Siragusa M, Happle R. Psoriasis and alopecia areata in a Down syndrome patient: a Renbök phenomenon. Eur J Dermatol 2017 Jun 01;27(3):300-301. [doi: 10.1684/ejd.2017.2977] [Medline: 28251896]

50. Sismour B, D'Acunto K. Down syndrome, severe psoriasis, and increased risk for cardiovascular events. JAAPA 2019 Dec;32(12):31-33. [doi: 10.1097/01.JAA.0000604860.71819.c1] [Medline: 31770302]

51. Sugiura K, Kitoh T, Watanabe D, Muto M, Akiyama M. Childhood-onset PsA in Down syndrome with psoriasis susceptibility variant CARD14 rs11652075. Rheumatology (Oxford) 2015 Jan 22;54(1):197-199. [doi: 10.1093/rheumatology/keu419] [Medline: 25342377]

52. Talamonti M, Galluzzo M, Chiricozzi A, Teoli M, Bavetta M, Costanzo A, et al. Ustekinumab for treatment of plaque psoriasis in a patient with Down syndrome. J Drugs Dermatol 2012 Aug;11(8):1000-1002. [Medline: 22859249]

53. Tudor RB. Letter: Psoriatic arthritis in a child with Down's syndrome. Arthritis Rheum 1976 May;19(3):651-651. [doi: 10.1002/art.1780190326] [Medline: 132938]

54. Wylie G, Burden D. Renbok phenomenon between psoriasis and alopecia areata. Clin Exp Dermatol 2011 Oct;36(7):816-817. [doi: 10.1111/j.1365-2230.2011.04097.x] [Medline: 21623882]

55. Bilgili SG, Akdeniz N, Karadag A, Akbayram S, Calka O, Ozkol HU. Mucocutaneous disorders in children with down syndrome: case-controlled study. Genet Couns 2011;22(4):385-392. [Medline: 22303799] 
56. Du Vivier A, Munro DD. Alopecia areata, autoimmunity, and Down's syndrome. Br Med J 1975 Jan 25;1(5951):191-192 [FREE Full text] [doi: 10.1136/bmj.1.5951.191] [Medline: 122906 ]

57. Roizen NJ, Magyar CI, Kuschner ES, Sulkes SB, Druschel C, van Wijngaarden E, et al. A community cross-sectional survey of medical problems in 440 children with Down syndrome in New York State. J Pediatr 2014 Apr;164(4):871-875. [doi: 10.1016/j.jpeds.2013.11.032] [Medline: 24367984]

58. Tan E, Tay Y, Giam Y. A clinical study of childhood alopecia areata in Singapore. Pediatr Dermatol 2002 Sep 13;19(4):298-301. [doi: 10.1046/j.1525-1470.2002.00088.x] [Medline: 12220271]

59. Lima Estefan J, Queiroz M, Costa FF, Coutinho MP, Higino K, Clinton Llerena J, et al. Clinical characteristics of alopecia areata in Down syndrome. Acta Dermatovenerol Croat 2013;21(4):253-258. [Medline: 24476614]

60. Ramot Y, Molho-Pessach V, Tenenbaum A, Zlotogorski A. Alopecia areata and down syndrome: a true association or a coincidence. Int J Trichology 2013 Oct;5(4):227-228 [FREE Full text] [doi: 10.4103/0974-7753.130425] [Medline: 24778541]

61. Schepis C, Barone C, Lazzaro Danzuso G, Romano C. Alopecia areata in Down syndrome: a clinical evaluation. J Eur Acad Dermatol Venereol 2005 Nov;19(6):769-770. [doi: 10.1111/j.1468-3083.2005.01259.x] [Medline: 16268894]

62. Bimbi C, Kyriakou G, Wollina U. Occlusive treatment enhances efficacy of tacrolimus $0.1 \%$ in a pediatric patient with severe alopecia areata: Case report and literature review. Pediatr Dermatol 2021 Jan 27;38(1):339-340. [doi: 10.1111/pde.14474] [Medline: 33247446]

63. Bordel-Gómez MT. Congenital triangular alopecia associated with Down's syndrome. J Eur Acad Dermatol Venereol 2008 Dec;22(12):1506-1507. [doi: 10.1111/j.1468-3083.2008.02683.x] [Medline: 18355199$]$

64. Dourmishev A, Miteva L, Mitev V, Pramatarov K, Schwartz RA. Cutaneous aspects of Down syndrome. Cutis 2000 Dec;66(6):420-424. [Medline: 11138359$]$

65. Hatamochi A, Ueki H. Successful treatment of alopecia areata with dinitrochlorobenzene in a patient with Down's syndrome. J Dermatol 1984 Apr;11(2):191-193. [doi: 10.1111/j.1346-8138.1984.tb01463.x] [Medline: 6237137]

66. Norton SA, Demidovich CW. Down syndrome, alopecia universalis, and trachyonychia. Pediatr Dermatol 1993 Jun;10(2):187-188. [doi: 10.1111/j.1525-1470.1993.tb00052.x] [Medline: 8346118]

67. Pirgon O, Atabek ME, Sert A. Diabetic ketoacidosis, thyroiditis and alopecia areata in a child with Down syndrome. Indian J Pediatr 2009 Dec 11;76(12):1263-1264. [doi: 10.1007/s12098-009-0242-7] [Medline: 20012788]

68. Rachubinski AL, Estrada BE, Norris D, Dunnick CA, Boldrick JC, Espinosa JM. Janus kinase inhibition in Down syndrome: 2 cases of therapeutic benefit for alopecia areata. JAAD Case Rep 2019 Apr;5(4):365-367 [FREE Full text] [doi: 10.1016/j.jdcr.2019.02.007] [Medline: 31008170]

69. Scotson J. A patient with Down's syndrome, mild hypothyroidism and alopecia. Practitioner 1989 Feb 08;233(1462):121. [Medline: 2529487]

70. Sethuraman G, Malhotra A, Sharma V. Alopecia universalis in Down syndrome: response to therapy. Indian J Dermatol Venereol Leprol 2006;72(6):454-455. [doi: 10.4103/0378-6323.29346] [Medline: 17179625]

71. Storm W. Celiac disease and alopecia areata in a child with Down's syndrome. J Intellect Disabil Res 2000 Oct;44(Pt 5):621-623. [doi: 10.1046/j.1365-2788.2000.00268.x] [Medline: 11079358]

72. Agarwal S, Ojha A, Gupta S. Profile of vitiligo in Kumaun region of Uttarakhand, India. Indian J Dermatol 2014;59(2):209. [doi: 10.4103/0019-5154.127706]

73. Agarwal S, Gupta S, Ojha A, Sinha R. Childhood vitiligo: clinicoepidemiologic profile of 268 children from the Kumaun region of Uttarakhand, India. Pediatr Dermatol 2013;30(3):348-353. [doi: 10.1111/pde.12032] [Medline: 23278409]

74. Aghaei S, Salmanpour R, Handjani F, Monabati A, Mazharinia N, Dastgheib L. Ulcerated disseminated cutaneous leishmaniasis associated with vitiligo, hypothyroidism, and diabetes mellitus in a patient with Down syndrome. Dermatology Online Journal 2004;10(2):21. [doi: 10.5070/D369w8k1sb]

75. Bonifaz A, Saúl A, Mena C, Valencia A, Paredes V, Fierro L, et al. Dermatophyte onychomycosis in children under 2 years of age: experience of 16 cases. J Eur Acad Dermatol Venereol 2007 Jan;21(1):115-117. [doi:

10.1111/j.1468-3083.2006.01802.x] [Medline: 17207185]

76. Gupta A, Chang P, Del Rosso J, Adam P, Hofstader S. Onychomycosis in children: prevalence and management. Pediatr Dermatol 1998 Nov;15(6):464-471. [doi: 10.1046/j.1525-1470.1998.1998015464.x] [Medline: 9875971]

77. Velthuis PJ, Nijenhuis M. Treatment of onychomycosis with terbinafine in patients with Down's syndrome. Br J Dermatol 1995 Jul;133(1):144-146. [doi: 10.1111/j.1365-2133.1995.tb02513.x] [Medline: $\underline{7669630}$ ]

78. Goulden V, Goodfield MJD. Treatment of childhood dermatophyte infections with oral terbinafine. Pediatr Dermatol 1995 Mar;12(1):53-54. [doi: 10.1111/j.1525-1470.1995.tb00126.x] [Medline: 7792222]

79. Riabi HRA. The Outbreak of Classic and Norwegian Type Scabies, in Mentally Handicapped Persons in a Rehabilitation Centre-Iran. JCDR 2019:7-12. [doi: 10.7860/jcdr/2019/38430.12743]

80. Assaf RR, Wu H. Visual Diagnosis: Severe Scaly Pruritic Rash in an 8-year-old Girl With Trisomy 21. Pediatr Rev 2016 Nov 01;37(11):e45-e47. [doi: 10.1542/pir.2015-0158] [Medline: 27803149]

81. Fonseca V, Price HN, Jeffries M, Alder SL, Hansen RC. Crusted scabies misdiagnosed as erythrodermic psoriasis in a 3-year-old girl with down syndrome. Pediatr Dermatol 2014 Oct 21;31(6):753-754. [doi: 10.1111/pde.12225] [Medline: 24138478] 
82. Senterre Y, Jouret G, Collins P, Nikkels AF. Risankizumab-Aggravated Crusted Scabies in a Patient with Down Syndrome. Dermatol Ther (Heidelb) 2020 Aug 06;10(4):829-834 [FREE Full text] [doi: 10.1007/s13555-020-00386-8] [Medline: 32378153]

83. Tschen E, Head E. Elastosis perforans serpiginosa and other complications. Arch Dermatol 1980 Dec;116(12):1348. [doi: 10.1001/archderm.1980.01640360022011] [Medline: $\underline{6450568]}$

84. Jayananda S, Raju G, Swamy N. Norwegian or Crusted Scabies in a Patient with Down Syndrome. Infectious Diseases in Clinical Practice 2013;21(5):318-319. [doi: 10.1097/IPC.0b013e318278f707]

85. Villibor F, Marchesini G, Roselino Ribeiro A, Guaré R. Cutaneous leishmaniasis in an indigenous infant with Down's syndrome: A case report. Asian Pac J Trop Med 2019;12(12):574-576. [doi: 10.4103/1995-7645.272488]

86. Ferreli C, Atzori L, Zucca M, Pistis P, Aste N. Leishmaniasis of the lip in a patient with Down's syndrome. J Eur Acad Dermatol Venereol 2004 Sep;18(5):599-602. [doi: 10.1111/j.1468-3083.2004.00987.x] [Medline: 15324405]

87. Abass K, Saad H, Abd-Elsayed AA. The first case of isolated facial cutanenous leishmaniasis in a Down syndrome infant: a case report and review of the literature. Cases J 2009 Jan 06;2(1):13-14 [FREE Full text] [doi: 10.1186/1757-1626-2-13] [Medline: 19126205]

88. Pardo M, Bonifaz A, Valencia A, Araiza J, Mejia SA, Mena-Cedillos C. Actinomycetoma by Nocardia brasiliensis in a girl with Down syndrome. Dermatology Online Journal 2008;14(8):9. [doi: 10.5070/D381q9w3bb]

89. Fox GN, Mehregan DA, Jablonowski MN. Acral milia-like idiopathic calcinosis cutis in a child with down syndrome: report of a case, review of the literature, and description of dermoscopic findings. Pediatr Dermatol 2013 Jan 26;30(2):263-264. [doi: 10.1111/j.1525-1470.2011.01673.x] [Medline: 22276686]

90. Kanzaki T, Nakajima M. Milialike idiopathic calcinosis cutis and syringoma in Down's syndrome. J Dermatol 1991 Oct 09;18(10):616-618. [doi: 10.1111/j.1346-8138.1991.tb03143.x] [Medline: 1838753]

91. Kotsuji T, Imakado S, Iwasaki N, Fujisawa H, Otsuka F. Milia-like idiopathic calcinosis cutis in a patient with translocation Down syndrome. J Am Acad Dermatol 2001 Jul;45(1):152-153. [doi: 10.1067/mjd.2001.113456] [Medline: 11423857]

92. Kumar P, Savant SS, Nimisha E, Das A, Debbarman P. Milia-like idiopathic calcinosis cutis in a child with Down syndrome. DOJ 2016 May 18;22(5):9. [doi: 10.5070/d3225030948]

93. Galbraith SS, Fairley JA, Esterly NB. White papules in a child with Down syndrome. Pediatr Dermatol 2002 Jun 13;19(3):271-273. [doi: 10.1046/j.1525-1470.2002.00068.x] [Medline: 12047651]

94. Motegi S, Sekiguchi A, Fujiwara C, Yamazaki S, Ishikawa O. Milia-like idiopathic calcinosis cutis and plaque-type syringoma in a girl with Down syndrome. J Dermatol 2019 Apr 08;46(4):e136-e137. [doi: 10.1111/1346-8138.14635] [Medline: $\underline{30194873}$ ]

95. Sais G, Jucglà A, Moreno A, Peyrí J. Milia-like idiopathic calcinosis cutis and multiple connective tissue nevi in a patient with Down syndrome. Journal of the American Academy of Dermatology 1995 Jan;32(1):129-130. [doi: 10.1016/0190-9622(95)90212-0]

96. Schepis C, Siragusa M, Palazzo R, Batolo D, Romano C. Perforating milia-like idiopathic calcinosis cutis and periorbital syringomas in a girl with Down syndrome. Pediatr Dermatol 1994 Sep;11(3):258-260. [doi: 10.1111/j.1525-1470.1994.tb00598.x] [Medline: 7971561]

97. Schepis C, Siragusa M, Palazzo R, Batolo D, Romano C. Milia-like idiopathic calcinosis cutis: an unusual dermatosis associated with Down syndrome. Br J Dermatol 1996 Jan;134(1):143-146. [doi: 10.1111/j.1365-2133.1996.tb07855.x]

98. Smith M, Golitz LE, Morelli JG, Weston WL, Markewich G. Milialike Idiopathic Calcinosis Cutis in Down's Syndrome. Arch Dermatol 1989 Nov 01;125(11):1586-1587. [doi: 10.1001/archderm.1989.01670230128029]

99. Solak B, Kara RO, Vargol E. Milia-like calcinosis cutis in a girl with Down syndrome. An Bras Dermatol 2016 Oct;91(5):655-657 [FREE Full text] [doi: 10.1590/abd1806-4841.20164560] [Medline: 27828644]

100. Turan E, Yurt N, Yeşilova Y, Tanrıkulu O. A rare association in Down syndrome: milialike idiopathic calcinosis cutis and palpebral syringoma. Cutis 2016 Dec;98(6):E22-E23. [Medline: 28099543]

101. Hattori M, Shimizu A, Ishikawa O. Dystrophic calcinosis cutis of the auricles after injury in Down's syndrome. J Dermatol 2018 Nov 14;45(11):e314-e316. [doi: 10.1111/1346-8138.14467] [Medline: 29756299]

102. Maroon M, Tyler W, Marks VJ. Calcinosis cutis associated with syringomas: A transepidermal elimination disorder in a patient with Down syndrome. Journal of the American Academy of Dermatology 1990 Aug;23(2):372-375. [doi: 10.1016/0190-9622(90)70225-7]

103. Choi S, Park S. Collagenoma in a Patient With Down Syndrome: A Case Report and Review of the Literature. Am J Dermatopathol 2018 May;40(5):355-357. [doi: 10.1097/DAD.0000000000000873] [Medline: 28398919]

104. Togawa Y, Nohira G, Shinkai H, Utani A. Collagenoma in Down syndrome. Br J Dermatol 2003 Mar;148(3):596-597. [doi: 10.1046/j.1365-2133.2003.05209 5.x] [Medline: 12653762]

105. Smith JB, Hogan DJ, Glass L, Fenske NA. Multiple collagenomas in a patient with Down syndrome. Journal of the American Academy of Dermatology 1995 Nov;33(5):835-837. [doi: 10.1016/0190-9622(95)91845-0]

106. Hafiji J, Hook CE, Burrows NP. Hyperkeratotic papules in a child with Down syndrome. Diagnosis: acquired reactive perforating collagenosis in Down syndrome. Pediatr Dermatol 2011;28(1):53-54. [doi: 10.1111/j.1525-1470.2010.01368.x] [Medline: 21276053] 
107. Honda M, Tomimura S, de Vega S, Utani A. Multiple dermatofibromas in a patient with Down syndrome. J Dermatol 2016 Mar 28;43(3):346-348. [doi: 10.1111/1346-8138.13189] [Medline: 26508658]

108. Tanaka M, Hoashi T, Serizawa N, Okabe K, Ichiyama S, Shinohara R, et al. Multiple unilaterally localized dermatofibromas in a patient with Down syndrome. J Dermatol 2017 Sep 26;44(9):1074-1076. [doi: 10.1111/1346-8138.13625] [Medline: 27665731]

109. Lamb R, Gangopadhyay M, MacDonald A. Multiple dermatofibromas in Down syndrome. Int J Dermatol 2014 Apr;53(4):e274-e275. [doi: 10.1111/ijd.12037] [Medline: 23879455]

110. Monteagudo B, Suárez-Amor O, Cabanillas M, León-Mateos A, Pérez-Valcárcel J, de las Heras C. [Down syndrome: another cause of immunosuppression associated with multiple eruptive dermatofibromas?]. Dermatol Online J 2009 Sep 15;15(9):15. [Medline: 19931002]

111. Jafarian F, Powell J, Kokta V, Champagne M, Hatami A, McCuaig C, et al. Malignant melanoma in childhood and adolescence: report of 13 cases. J Am Acad Dermatol 2005 Nov;53(5):816-822. [doi: 10.1016/j.jaad.2005.07.013] [Medline: 16243130]

112. Satgé D, Dimoux-Dime G, Godard W, de Fréminville B. Adolescent girl with Down syndrome and lumbar cutaneous melanoma. Pediatr Dermatol 2014 May 29;31(1):108-109. [doi: 10.1111/j.1525-1470.2012.01764.x] [Medline: 22639836]

113. Nakano J, Muto M, Arikawa K, Hirota T, Asagami C. Acral lentiginous melanoma associated with Down's syndrome. J Dermatol 1993 Jan 09;20(1):59-60. [doi: 10.1111/j.1346-8138.1993.tb03831.x] [Medline: $\underline{8482754]}$

114. Butterworth T, Strean LP, Beerman H, Gray Wood M. Syringoma and Mongolism. Arch Dermatol 1964 Nov 01;90(5):483-487. [doi: 10.1001/archderm.1964.01600050031007]

115. Feingold M. Syringomas in Down syndrome. Am J Dis Child 1991 Sep 01;145(9):966-967. [doi: 10.1001/archpedi.1991.02160090016006] [Medline: 1831593]

116. Alsabbagh M, Raees M. Eruptive Syringoma. BMB 2014 Mar;36(1):46-47. [doi: 10.12816/0004469]

117. Seo S, Oh C, Kwon K, Kim M. A case of milium-like syringoma with focal calcification in Down syndrome. Br J Dermatol 2007 Sep;157(3):612-614. [doi: 10.1111/j.1365-2133.2007.07967.x] [Medline: 17553057]

118. Abdullah L, Abbas O. Keratotic papules and plaques in an adolescent with Down syndrome. Clin Exp Dermatol 2010 Dec;35(8):935-936. [doi: 10.1111/j.1365-2230.2010.03863.x] [Medline: 21054489]

119. Crotty G, Bell M, Estes SA, Kitzmiller KW. Cytologic features of elastosis perforans serpiginosa (EPS) associated with Down's syndrome. Journal of the American Academy of Dermatology 1983 Feb;8(2):255-256. [doi: 10.1016/s0190-9622(83)80184-4]

120. De Pasquale R, Nasca M, Musumeci M, Micali G. Elastosis perforans serpiginosa in an adult with Down's syndrome: report of a case with symmetrical localized involvement. J Eur Acad Dermatol Venereol 2002 Jul;16(4):387-389. [doi: 10.1046/j.1468-3083.2002.00541.x] [Medline: $\underline{12224699]}$

121. Espinosa PS, Baumann RJ, Vaishnav AG. Elastosis perforans serpiginosa, Down syndrome, and moyamoya disease. Pediatr Neurol 2008 Apr;38(4):287-288. [doi: 10.1016/j.pediatrneurol.2007.12.014] [Medline: 18358411]

122. Gregersen PA, Stausbøl-Grøn B, Ramsing M, Sommerlund M. Elastosis Perforans Serpiginosa in a patient with Down syndrome treated with imiquimod 5\% cream. Dermatol Reports 2010 Aug 31;2(2):15-43 [FREE Full text] [doi: 10.4081/dr.2010.e15] [Medline: 25386246]

123. Hernández-Ruiz E, García-Herrera A, Ferrando J. Scaly Erythematous Patches in a Patient With Down Syndrome. Actas Dermo-Sifiliográficas (English Edition) 2015 Nov;106(9):753-754. [doi: 10.1016/j.adengl.2015.09.021]

124. Kaufman J. Reticulated and Linear Atrophic Scarring in Elastosis Perforans Serpiginosa. Cutis 1975;15(5):724-725. [doi: $10.1007 /$ springerreference 40962]

125. Kaufman AJ. Treatment of elastosis perforans serpiginosa with the flashlamp pulsed dye laser. Dermatol Surg 2000 Nov;26(11):1060-1062. [doi: 10.1046/j.1524-4725.2000.0260111060.x] [Medline: 11096396]

126. O'Donnell B, Kelly P, Dervan P, Powell FC. Generalized elastosis perforans serpiginosa in Down's syndrome. Clin Exp Dermatol 1992 Jan;17(1):31-33. [doi: 10.1111/j.1365-2230.1992.tb02529.x] [Medline: 1424255]

127. Pereira ACF, Baeta IGR, Costa Júnior SRD, Gontijo Júnior OM, Vale ECSD. Elastosis perforans serpiginosa in a patient with Down's syndrome. An Bras Dermatol 2010 Oct;85(5):691-694. [doi: 10.1590/s0365-05962010000500015] [Medline: 21152796]

128. Polańska A, Bowszyc-Dmochowska M, Żaba RW, Adamski Z, Reich A, Dańczak-Pazdrowska A. Elastosis perforans serpiginosa: a review of the literature and our own experience. Postepy Dermatol Alergol 2016 Oct;33(5):392-395 [FREE Full text] [doi: 10.5114/ada.2016.62849] [Medline: 27881947]

129. Rasmussen JE. Disseminated elastosis perforans serpiginosa in four mongoloids. Recognition of residual changes. Br J Dermatol 1972 Jan;86(1):9-13. [doi: 10.1111/j.1365-2133.1972.tb01885.x] [Medline: 4258486]

130. Scherbenske JM, Benson PM, Rotchford JP, James WD. Cutaneous and ocular manifestations of Down syndrome. Journal of the American Academy of Dermatology 1990 May;22(5):933-938. [doi: 10.1016/0190-9622(90)70129-6]

131. Suneja T, Zelonis B, Hurley MY, Youker SR. Elastosis perforans serpiginosa. Skinmed 2007 Sep;6(5):255-256. [doi: 10.1111/j.1540-9740.2007.06438.x] [Medline: 17786109$]$

132. Treadwell PA. Hyperkeratotic papules in a patient with Down syndrome. Pediatr Dermatol 1990 Sep;7(3):237-238. [doi: 10.1111/j.1525-1470.1990.tb00289.x] [Medline: 2147238] 
133. Mehta R, Burrows N, Payne CM, Mendelsohn S, Pope F, Rytina E. Elastosis perforans serpiginosa and associated disorders. Clin Exp Dermatol 2001 Sep;26(6):521-524. [doi: 10.1046/j.1365-2230.2001.00882.x] [Medline: 11678881]

134. Siragusa M, Romano C, Cavallari V, Schepis C. Localized elastosis perforans serpiginosa in a boy with Down syndrome. Pediatr Dermatol 1997 May;14(3):244-246. [doi: 10.1111/j.1525-1470.1997.tb00250.x] [Medline: 9192425]

135. Schepis C, Siragusa M. Secondary anetoderma in people with Down's syndrome. Acta Derm Venereol 1999 May 28;79(3):245 [FREE Full text] [doi: 10.1080/000155599750011174] [Medline: 10384937]

136. Madke B, Ghia D, Gadkari R, Nayak C. Cheilitis granulomatosa (Miescher granulomatous macrocheilitis) with trisomy 21. Dermatology Online Journal 2012;18(6):7. [doi: 10.5070/D33m34c0p4]

137. Catalán JA, Rodríguez FA, Yubero M, Palisson F, Gana MJ, Krämer SM, et al. De Novo COL7A1 mutation in a patient with trisomy 21: coexistence of dystrophic epidermolysis bullosa and Down syndrome. Int J Dermatol 2012 Sep;51(9):1078-1081. [doi: 10.1111/j.1365-4632.2011.05428.x] [Medline: 22909362]

138. Hazelrigg D. Generalized perforating granuloma annulare: a case report and review of the literature. Cutis 1979 Jun;23(6):813-814. [Medline: 157261]

139. Alfadley A, Al Hawsawi K, Hainau B, Al Aboud K. Two brothers with keratosis follicularis spinulosa decalvans. J Am Acad Dermatol 2002 Nov;47(5 Suppl):S275-S278. [doi: 10.1067/mjd.2002.110663] [Medline: 12399750]

140. De Berker DA, Wilson CL, Millard PR. Reactive perforating collagenosis and Down's syndrome. Br J Dermatol 1992 Jan;126(1):71-73. [doi: 10.1111/j.1365-2133.1992.tb08407.x] [Medline: 1531611]

141. Lappe U, Aumann V, Mittler U, Gollnick H. Familial urticaria pigmentosa associated with thrombocytosis as the initial symptom of systemic mastocytosis and Down's syndrome. J Eur Acad Dermatol Venereol 2003 Nov;17(6):718-722. [doi: 10.1046/j.1468-3083.2003.00834.x] [Medline: 14761147 ]

142. Bull MJ, Committee on Genetics. Health supervision for children with Down syndrome. Pediatrics 2011 Aug 25;128(2):393-406. [doi: 10.1542/peds.2011-1605] [Medline: 21788214]

143. Lam M, Lai C, Almuhanna N, Alhusayen R. Hidradenitis suppurativa and Down syndrome: A systematic review and meta-analysis. Pediatr Dermatol 2020 Nov 06;37(6):1044-1050. [doi: 10.1111/pde.14326] [Medline: 32892406]

144. Jones JT, Talib N, Lovell D, Becker ML. Clinical Features and Treatment of Down Syndrome Arthropathy: Experience from Two US Tertiary Hospitals. Paediatr Drugs 2019 Feb 13;21(1):33-39. [doi: 10.1007/s40272-018-0322-0] [Medline: $\underline{30547384}$ ]

\section{Abbreviations}

AA: alopecia areata

AD: atopic dermatitis

DS: Down syndrome

EPS: elastosis perforans serpiginosa

HS: hidradenitis suppurativa

IFN- $\gamma$ : interferon gamma

LN: lichen nitidus

PRISMA: Preferred Reporting Items for Systematic Reviews and Meta-Analyses

PROSPERO: International Prospective Register of Systematic Reviews

PRP: pityriasis rubra pilaris

TNF- $\alpha$ : tumor necrosis factor alpha

Edited by R Dellavalle, T Sivesind; submitted 05.09.21; peer-reviewed by S Gulliver, T Ewais; comments to author 28.11.21; revised
version received 19.12.21; accepted 20.12.21; published 08.02.22
Please cite as:
Lam M, Lu JD, Elhadad L, Sibbald C, Alhusayen R
Common Dermatologic Disorders in Down Syndrome: Systematic Review
JMIR Dermatol 2022;5(1):e33391
URL: https://derma.jmir.org/2022/1/e33391
doi: 1 10.2196/33391
PMID:

CMegan Lam, Justin Di Lu, Levi Elhadad, Cathryn Sibbald, Raed Alhusayen. Originally published in JMIR Dermatology (http://derma.jmir.org), 08.02.2022. This is an open-access article distributed under the terms of the Creative Commons Attribution License (https://creativecommons.org/licenses/by/4.0/), which permits unrestricted use, distribution, and reproduction in any medium, provided the original work, first published in JMIR Dermatology Research, is properly cited. The complete bibliographic 
information, a link to the original publication on http://derma.jmir.org, as well as this copyright and license information must be included. 